\title{
Correction to: REALMS study: real-world effectiveness and safety of fingolimod in patients with relapsing-remitting multiple sclerosis in Portugal
}

\author{
S. Batista ${ }^{1}$ - C. C. Nunes ${ }^{1} \cdot$ J. J. Cerqueira ${ }^{2,3} \cdot$ Ana Martins Silva $^{4,5} \cdot$ J. Correia de Sá $^{6} \cdot$ J. Ferreira $^{6} \cdot$ M. T. Mendonça ${ }^{7}$. \\ J. Pinheiro ${ }^{8}$ - V. Salgado ${ }^{9}$ - A. S. Correia ${ }^{10} \cdot$ J. Sequeira ${ }^{11}$ - A. Costa ${ }^{12} \cdot$ L. Sousa $^{1}$
}

Published online: 9 November 2020

(C) Fondazione Società Italiana di Neurologia 2020

\section{Correction to: Neurological Sciences (2020). https://doi.org/10.1007/s10072-020-04726-6}

The article "REALMS study: real-world effectiveness and safety of fingolimod in patients with relapsing-remitting multiple sclerosis in Portugal", written by S. Batista, C. C. Nunes, J. J. Cerqueira, Ana Martins Silva, J. Correia de Sá, J. Ferreira, M. T. Mendonça, J. Pinheiro, V. Salgado, A. S. Correia, J. Sequeira, A. Costa, L. Sousa, was originally published electronically on the publisher's internet portal on 30 September 2020 without open access. With the author(s)' decision to opt for Open Choice the copyright of the article changed on 03 November 2020 to (C) The Author(s) 2020 and the article is forthwith distributed under a Creative Commons Attribution 4.0 International License, which permits use, sharing, adaptation, distribution and reproduction in any medium or format, as long as you give appropriate credit to the original author(s) and the source, provide a link to the Creative Commons license, and indicate if changes were made. The images or other third party material in this article are included in the article's Creative Commons license, unless indicated otherwise in a credit line to the material. If material is not included in the article's Creative Commons license and your intended use is not permitted by statutory regulation or exceeds the permitted use, you will need to obtain permission directly from the copyright holder. To view a copy of this license, visit http://creativecommons.org/licenses/by/4.0.

The original article has been corrected.

Publisher's note Springer Nature remains neutral with regard to jurisdictional claims in published maps and institutional affiliations.

6 Centro Hospitalar Lisboa Norte E. P. E, Hospital de Santa Maria, Lisbon, Portugal

7 Centro Hospitalar São João, Porto, Portugal

8 Centro Hospitalar Vila Nova Gaia, Vila Nova de Gaia, Portugal

9 Hospital Prof. Doutor Fernando Fonseca E. P. E, Amadora, Portugal

10 Centro Hospitalar de Lisboa Ocidental E. P. E, Hospital de Egas Moniz, Lisbon, Portugal

11 Centro Hospitalar Universitário de Lisboa Central E.P.E, Hospital Santo António dos Capuchos, Lisbon, Portugal

12 Novartis Farma, Lisbon, Portugal 